\title{
CIVIL PROCEDURE: FINDINGS IN CIVIL ACTION NOT RES JUDICATA IN SUBSE- QUENT LONGSHOREMAN'S ACT CLAIM
}

In Young \& Co.v. Shea the Court of Appeals for the Fifth Circuit ruled that the judicial doctrine of collateral estoppel will not be applied to findings of fact madc by a jury in a prior civil action when the same issue later arises before a deputy commissioner under the Longshoremen's and Harbor Workers' Compensation Act. ${ }^{2}$ The claimant longshoreman, Tugwell, had previously instituted a civil action against a shipowner based upon the traditional tort theory of negligence and the unseaworthiness doctrine. ${ }^{3}$ The shipowner impleaded the stevedoring firm of Young \& Co., Tugwell's employer. In response to a special interrogatory, ${ }^{4}$ the jury found that Tugwell had not been involved in an accident and had not suffered an injury, and judgment was accordingly entered for the shipowner. Tugwell then instituted proceedings under the Longshoremen's Act to recover compensation from Young \& $\mathrm{Co}$. for the alleged injury. Over the employer's objection, the Commission refused to apply the doctrine of collateral estoppel; found that Tugwell had sustained the injury as claimed; and awarded compensation. The employer appealed, arguing that the Commissioner had crred in failing to apply the previous judicial determination that Tugwell had not been injured, and that the prior action should collaterally estop Tugwell from again asserting the same injury as the basis of a workmen's compensation claim. Both the district court and the Court of Appeals for the Fifth Circuit affirmed.

Collateral estoppel is that aspect of res judicata which precludes relitigation of specific facts or issues once thosc questions have been judicially determined..$^{5}$ Generally, the application of the doctrine is

1397 F.2d 185 (5th Cir. 1968).

233 U.S.C. $\$ 901-50$ (1964).

${ }^{3}$ Tugwell v. A.F. Klaveness \& Co., 320 F.2d 866 (5th Cir. 1963), cert. denied, 376 U.S. 951 (1964).

+ Id. at 868 n.1.

${ }^{3}$ See generally Hoag v. New Jersey, 356 U.S. 464, 470 (1958); Cromwell v. County of Sac, 94 U.S. 351 (1876); Peckham v. Family Loan Co., 196 F.2d 838 (5th Cir. 1952); F. JAMEs, Civil Procedure $\$ 11.9$ (1965); Restatement of Judgments $\S 45$, comment c (1942); Scott, 
limited to those facts which were finally and necessarily determined in the prior action. ${ }^{6}$ This limitation, with its underlying rationale of judicial expediency and efficiency, is based upon the principle that every man is entitled to his day in court, but that he shall not be heard a second time on an issue which he has already been permitted to contest. ${ }^{7}$ There are three criteria which must be satisfied before the doctrine of collateral estoppel will be applied. These include whether the fact or issue determined in the prior action is identical with the question presented in the present action; ${ }^{8}$ whether the party against whom the doctrine is pleaded was a party to, or in privity with a party to, the prior action; ${ }^{9}$ and whether the issue in question was conclusively and necessarily determined in the prior action. ${ }^{10}$ When these criteria are met, the doctrine applies and factual determinations made in the prior action are accepted as binding upon a court in any subsequent proceeding.

Collateral estoppel, essentially a judicial doctrine applying only to bodies exercising a judicial function," has been less consistently applied in the field of administrative law than it has in strictly judicial areas. ${ }^{12}$ Thus, administrative invocation of the doctrine depends upon the purpose and function of the agency before which a hearing is being conducted. It does not apply to those agencies or boards whose functions are primarily legislative or regulatory. ${ }^{13}$ The distinction between those agencies which are judicial, or "quasi-judicial," and hence subject to the doctrine, however, and those which are essentially ministerial is a difficult one to draw. A "quasi-judicial" administrative agency is one empowered to ascertain facts from

Collateral Estoppel by Judgment, 56 HaRv. L. Rev. 1 (1942); Developments in the Law-Res Judicata, 65 HARV. L. REV. 818 (1952); 36 N.Y.U.L. REV. 522 (1961):

'See, e.g., F. JAMES, supra note 5 , at $\$ \$ 11.19-.21$.

'See, e.g., Masterson v. Atherton, 328 F.2d 106 (2d Cir. 1964); United States v. Burch, 294 F.2d 1 (5th Cir. 1961); Worley v. Dunn, 252 F.2d 712 (6th Cir.), cert. denied, 358 U.S. 848 (1958); Vanderveer v. Erie Malleable Iron Co., 238 F.2d 510 (3d Cir. 1956), cert: denied, 353 U.S. 937 (1957); Wallingsford v. Larcon Co., 237 F.2d 904 (8th Cir. 1956).

${ }^{8}$ See, e.g., Cromwell v. County of Sac, 94 U.S. 351 (1876).

'See, e.g., F. JAMES, supra note 5.

${ }^{10}$ See, e.g., id., at § 11.18; Polasky, Collateral Estoppel-Effects of Prior Litigation, 39 lowa L. REv. 217 (1954).

"See, e.g., Arizona Grocery Co. v. Atchison, T. \& S.F.Ry., 284 U.S. 370 (1931).

${ }^{2}$ See, e.g., 2 K. Davis, Administrative Law 545 (1958); Groner \& Sternstein, Res Judicata in Federal Administrative Law, 39 Iowa L. Rev. 300 (1954); Parker, Administrative Res Judicata, 40 ILL. L. REV. 56 (1945); Comment, Res Judicata in Administrative Law, 49 YALE L.J. 1250 (1940).

${ }^{13}$ See, e.g., Arizona Grocery Co. v. Atchison, T. \& S.F.Ry., 284 U.S. 370, 389 (1931). 
evidence and to apply the law to the facts through the use of judicial discretion. ${ }^{14}$ The actions of such agencies usually take the form of fines, restrictions or positive orders directing affirmative action on the part of the losing party. Workmen's compensation boards and labor relations boards are examples. Agencies whose functions are primarily ministerial or legislative are those which, like the FTC, 1CC, IRS and Patcnt Office, confine their judgments to prospective regulations, tariff limits, allowable tax deductions and the like. ${ }^{15}$ It has frequently been held that a court is bound by collateral estoppel to the prior findings of an administrative agency. Thus, in Drier $v$. Randforce Amusement Corp. ${ }^{16}$ a case presenting the converse of the situation posed in Young \& Co., the finding of a workmen's compensation board that Drier had suffered no injury was held to estop Drier from alleging the same injury in a subsequent tort action against his employer. When, as in Young \& Co., the administrative proceeding arises after a judicial determination, the applicability of the doctrine would seem to be influenced by a balancing of the legislative intent and purpose of the administrative tribunal against judicial expediency and fairness to the individual litigants. In those cases in which it is felt that an adverse administrative ruling would work undue hardship on a party whose status has already been judicially determined, collateral estoppel is applied. ${ }^{17}$ In other cases, the policy factors governing the origin and powers of the agency are found to take precedence over the policy considerations upon which collateral estoppel is based. ${ }^{18}$ In New York State Labor Relations Board v. Holland Laundry, ${ }^{19}$ for instance, an employer who had already been adjudged correct and within the law in a labor dispute was ordered to reinstate striking workers by the state labor relations

\footnotetext{
' See, e.g., Pope v. United States, 323 U.S. I (1944); County Farm Bureau v. Board of Supervisors, 218 Iowa 937, 252 N.W. 498 (1934); Pennsylvania R.R. v. State Aviation Comm'n, 2 N.J. 64, 65 A.2d 61 (1949); Dunbar v. Fant, 170 S.C. 414, 170 S.E. 460 (1933);

Kirby Lumber Co. v. Adams, 62 S.W.2d 366 (Tex. Civ. App. 1933).

is See Arizona Grocery Co. v. Atchison, T. \& S.F.Ry. 284 U.S. 370 (1931).

${ }_{16} 14$ Misc. 2d 362, 179 N.Y.S.2d 412 (Sup. Ct. 1958). See also Westgatc-Sun Harbor Co. v. Watson, 206 F.2d 458 (D.C. Cir. 1953).

"See, e.g., Bennett v. Commissioner, 113 F.2d 837 (5th Cir. 1940); George H. Lee Co. v. FTC, 113 F.2d 583 (8th Cir. 1940).

${ }^{13}$ See, e.g., K. Davis, supra note 12, at $\S 18.11$. See generally Slocum v. Delaware, L. \& W.R.R., 339 U.S. 239 (1950) (dictum); Miller v. Railroad Comm'r, 9 Cal. 2d 190, 70 P.2d 164 (1937); Williams Mfg. Co., 6 N.L.R.B. 135 (1938).

${ }^{19} 294$ N.Y. 480, 63 N.E.2d 68 (1945). For a detailed analysis of this case see Jaffe, The Public Right Dogma in Labor Board Cases, 59 HaRv L. Rev. 720 (1946).
} 
board. The board refused to abide by the facts as previously judicially determined. In upholding the board's action, although reversing the reinstatement order, the court held that the policy considerations served by res judicata were not equal in weight with the public interest served by the labor relations board. No prior determinations of fact, it said, should prevent the board from making its own investigation in the public interest.

After first noting that Young \& Co. presented a situation where collateral estoppel would normally be applied, the court proceeded to recognize two factors involved in the subsequent administrative hearing which precluded application of the doctrine. Of primary importance to the court was the level of proof necessary to establish a claim under the Act. The court concluded that a "less stringent standard of persuasion" 20 is needed to establish a fact before a commissioner than is necessary to prove the identical fact before a jury. Finding an analogous situation in the different burdens of persuasion carried by the parties in criminal and civil actions, the court reasoned that failure to prove the injury in a civil proceeding should not preclude subsequent efforts to establish the same injury before a commissioner, any more than should failure to prove a criminal act prevent an attempt to recover for tortious conduct. The court was unable to ascribe a legal label to the burden before a commissioner but was satisfied that it was lighter. The civil-criminal analogy and the statutory policy of resolving all doubtful questions of fact in favor of the employee provided the major premise of the court's logic. The second factor leading to the court's conclusion was the underlying policy of workmen's compensation laws. It is the policy of the Act, the court noted, to place the burden of loss upon those best able to bear it. Having failed to convince a jury, Tugwell still had access to the statutory remedy provided by the Act, and the court could find nothing that would operate to deny this recourse in light of the duality of remedies envisioned by Congress. ${ }^{21}$

The importance of Young \& Co. lies in the fact that for the first time the lower quantum of proof required to establish a workmen's compensation claim before a commissioner has been held to be, in itself, a bar to the defensive plea of collateral estoppel when that plea

\footnotetext{
20397 F.2d at 188.

"See, e.g., Reed v. The Yaka, 373 U.S. 410 (1963); Seas Shipping Co. v. Sieracki, 328 U.S. 85,100 (1946).
} 
is made by a party who has prevailed in prior civil litigation. However, the fact that the case arose in a workmen's compensation setting should perhaps be viewed as limiting both the decision and the import of the burden of proof consideration. The difference in the burden of proof before a civil court and an administrative tribunal is necessarily an uncertain concept-one that defies clear verbalization. It has even been suggested that there is no real difference between the two. ${ }^{22}$ The court, however, was able to buttress the unsteady framework of the burden of proof concept by invoking the policy considerations of the Compensation Act. As was the Holland Laundry court, ${ }^{23}$ the Young court was undoubtedly conscious of the public interest in assuring that any injured employee receives some form of insurance compensation, almost regardless of the employer's culpability. Such strong policy considerations do not necessarily pervade other areas of administrative law, and the court itself was careful to mention that the policies of the Longshoremen's Act are not necessarily applicable in other settings. ${ }^{24}$ This observation, made in reference to cases involving, among others, the FTC and IRS, implies that at least in these areas, the policy considerations of collateral estoppel may prevail. The Young \& Co. decision, therefore, should be confined to the context in which the case arose. An attempt to extend it beyond the workmen's compensation area would more than likely be rejected as an unwarranted interference with established principles of collateral estoppel.

\footnotetext{
${ }^{22}$ Bernstein v. Real Estate Comm'n, 221 Md. 221, 156 A.2d 657 (1959).

${ }^{23}$ See note 19 supra.

2s 397 F.2d at 188 n. 1 .
} 